\title{
Gramatical Cohesion and Lectical Cohesion in Text Report on Student Observation Results
}

\author{
Ainiyah Ekowati ${ }^{1)}$, Aceng Rahmat ${ }^{2)}$, Fathiaty Murtadho ${ }^{3)}$ \\ ${ }^{1)}$ Universitas Negeri Jakarta, Jakarta, Indonesia \\ E-mail:ainiyahekowati86@gmmail.com
}

\begin{abstract}
The use of cohesion in text can create relationships between elements of language in communication so that effective communication is created for language users. This study aims to describe the use of grammatical cohesion and lexical cohesion in the text of the report on the results of the observation of Indonesian Language and Literature Education Study Program at Pakuan University, Bogor. This study uses a descriptive and qualitative approach while the method used is the method proposed by Halliday and Hasan regarding cohesion. Based on the results of the research conducted, it was found that the use of grammatical cohesion in the form of references, substitutions, ellipsis and conjunctions, and lexical cohesion consisted of synonymy, hypernymy and collocation in the observation report text of Indonesian Language and Literature Education Study Program at Bogor Pakuan University.
\end{abstract}

Keywords: Grammatical Cohesion; Lexical Cohesion; Report Text on Observation Results

\section{INTRODUCTION}

The text of the report on the observations of students from the Indonesian Language and Literature Education Study Program, FKIP, Bogor Pakuan University as the final task of writing skills courses are written based on information obtained in the field. The compiled text should be documented, recorded, and arranged clearly and concisely. In accordance with Emilia's report that report / report (descriptive report, which is a type of text that presents information clearly and concisely (Emilia, 2012).

The information conveyed in the form of text can be well understood if it meets the requirements of cohesion and coherence. Cohesion is the harmonious relationship between one element and another element in the discourse so that it creates a neat or coherent understanding (Moeliono, 1988). Coherence is the harmony of meaning between discourse elements. The use of cohesion in the text in order to create relationships that are closely interrelated between the language elements used in the communication. Thus, effective and efficient communication between language users can be created.

There are two types of cohesion that are used to link language elements, namely grammatical cohesion, and lexical cohesion. The use of grammatical cohesion in the text of the report on the observations of students of the
Indonesian Language and Literature Study Program, FKIP, Bogor Pakuan University is not only limited to the use of syntactic units in the sentence. However, the use of grammatical cohesion is also present in the use of discourse units. To find out the extent to which grammatical and lexical cohesion phenomena are realized by students in writing reports on their observations, research on grammatical cohesion and lexical cohesion in the text of the observation report of Indonesian Language and Literature Education Study Program, FKIP, Pakuan University, Bogor needs to be done. In this regard, the issues discussed in this study are what evidence supports that in the text of the report on the observations of students from the Indonesian Language and Literature Education Study Program, FKIP, Pakuan University, Bogor there are uses of grammatical cohesion and lexical cohesion. In addition, the device is used in grammatical cohesion, and lexical cohesion in the text of report reports from observations by students of the Indonesian Language and Literature Education Study Program, FKIP, Pakuan University, Bogor.

\section{RESEARCH METHOD}

This study aims to describe the use of grammatical cohesion and lexical cohesion in the report text of student observation in the Indonesian Language and Literature Education Study Program, FKIP, Pakuan University. This 
study uses a descriptive and qualitative approach. The method used to analyze content in this study is the method proposed by Halliday and Hasan regarding cohesion.

The data source of this study is 8 text reports on the results of observation by students of the Indonesian Language and Literature Education Study Program, FKIP, Pakuan University. The research data is in the form of observation report text fragments which are thought to contain grammatical cohesion and lexical cohesion.

The data analysis procedure in this study uses the following work procedures.

a. Describe grammatical cohesion according to the theory of Halliday and Hassan in each text sentence of the observation report.

b. Describe lexical cohesion according to the theory of Halliday and Hassan in each text sentence of the observation report.

c. Use a table to classify the cohesion tool.

\section{DISCUSSION}

Based on data on 8 texts that have been analyzed, there are 383 sentences containing the tools of grammatical cohesion and lexical cohesion. Here's the explanation.

1. Grammatical Cohesion

Grammatical cohesion is used to indicate the existence of a form of relationship (language) between discourse-building sentences (Junaiyah: 27). Grammatical cohesion consists of references, substitution, ellipsis, and conjunction.

a. Reference

Reference consists of endophoric reference and exophoric reference. Endophoric reference (the relation is in the text) consists of anaphoric reference and cataphoric reference, while the exophoric reference (relation outside the text) depends on the situational context.

Based on the reference direction, endophoric reference can be divided into anaphoric reference and reference to cataphoric. Anaphoric reference is a reference which the referent (its reference) already mentioned (in oral discourse) or already written (in Indonesian written discourse, something that has been written down is located on the left). Therefore, anaphoric reference is also commonly called reference to the left (Halliday and Hassan: 76). The element that precedes or follows the referral is called antisedene. Antecedents are elements that precede (in anaphoric reference) or that follow (in cataphoric reference) referenced by words or expressions in a clause or sentence (Syamsudin: 28).

Reference cohesion marks a cohesive relationship of discourse through reference. There are three markers of cohesive reference referencing, namely referential personal, referential, and referential comparative. To prove whether in the text of the report on the results of observations by students of the Indonesian Language and Literature Education Study Program, FKIP, Pakuan University, there is reference to the following: data on the use of grammatical cohesion are presented in the fragments of the observation report text.

(1) Dari salah satu pengunjung Kebun Raya yang diwawancarai tujuan utama mengapa berkunjung ke Kebun Raya, karena suasananya yang sejuk yang di atapi oleh pohon-pohon besar untuk berlindung dari sinar matahari langsung. (2)Kegiatan yang biasanya dilakukan oleh pengunjung yang berwisata ke Kebun Raya Bogor itu relatif, pada umumnya tempat wisata lainnya Kebun Raya juga bisaanya dijadikan tempat rekreasi oleh wisatawan yang datang ke sana.

Reference to sentence 1 (one) that is klitik -nya to the word suasananya refers to the antecedent mentioned earlier, namely the Botanical Garden. This reference type is anaphoric because the referent (reference) has been written before or has been written it is located on the left. Besides that, the clitics - nya are included in the referential persona.

Reference / referential in sentence 2 (two), there includes demonstrative because it shows something (antecedent) inside or outside the precise discourse of place pronoun (locational).

b. Substitution

In the text of the report on the observations of students from the Indonesian Language and Literature Education Study Program, FKIP, Pakuan University, which is the data of this study, also found sentences that have a relationship of recovery. A recovery relationship is a cohesive relationship that states reimbursement. In a discourse that contains a relationship of recovery, there is an element of other discourse.

(3) Dan bukan hanya disediakannya sepeda keliling tetapi ada pula mobil keliling yang mengantarkan wisatawan untuk mengelilingi kebun raya, dengan tourage yang memberitahu tentang tanaman-tanaman apa saja yang ada dikebun raya, dengan tarif yang relatif terjangkau maka dari itu banyak wisatawan yang mengantri untuk menaiki mobil keliling tersebut.

Recovery cohesion in the text fragment (3) the word mobil keliling in the mobil keliling phrase, the substitution of the word tourage in the same sentence is a nominal type cohesive recovery relationship.

The sentence that reflects the relationship of recovery is also found in the text of the report on the observation of the students of the Indonesian Language and Literature Education Study Program, FKIP, Pakuan University as follows.

(4) Tujuan pengunjung yang datang ke kebun raya biasanya untuk mengisi waktu liburan, mencari suasana yang sejuk karena di kebun raya banyak pohon-pohon besar yang membuat sejuk dan membuat para wisatawan nyaman karena terlindungi dari sengatan mata- 
hari langsung, selain itu juga ada yang sengaja datang kesana untuk meneliti suatu tumbuhan yang berada di kebun raya tersebut.

The word wisatawan in the phrases of para wisatawan is a substitution of the pengunjung word in the phrase of pengunjung yang datang ke kebun raya.

\section{c. Ellipsis (Ellipsis)}

Elipsis is the removal of one part of the element of the sentence (Lubis: 38). Actually ellipsis is the same process with substitution, but this ellipsis is substituted by something that is empty or something that is not (zero). Naming impingement can be a syntactic function or role. Each part of the sentence supports certain syntactic functions. There are five syntactic functions in Indonesian, namely subject, predicate, object, complement, and description. The use of the correct syntactic function makes the sentence meaning intact and complete in accordance with the context. This happens because the syntactic function of the sentence causes the sentence to become a complete proposition.

The integrity of the idea occurs if the syntactic function is clearly stated and not disturbed by other words. The sentence becomes unclear because the syntactic function is also unclear. The unclear sentence is the same as a sentence that is not good and not right. Based on the data of this study in the form of a report text from the observations of students of the Indonesian Language and Literature Education Study Program, FKIP, Pakuan University, sentences were found which showed cohesive relationships of lapses. The following sentence (5) is classified as a sentence that has a cohesive relationship.

(5) Bunga bangkai Amorphophallus merupakan tumbuhan asli Sumatera dengan rangkaian bunga tertinggi dan terbesar di dunia.

In sentence (5) the largest clause in the world subject is subject to lapse, namely the flower sequence phrase mentioned in the previous clause. This can be done without reducing the meaning of the sentence. The same element that is not eroded is the antecedent of the element that is dissolved. The device used to cross the antecedents in the text fragment (5) is the rangkaian bunga phrase. The antecedent it refers to is rangkaian bunga. The antecedents have been mentioned before. Endophora that occurs in fragments of text (5) is anaphorous, because it cross-references the antecedents mentioned earlier.

d. Conjunction

In the text of the report on the observations of students from the Indonesian Language and Literature Education Study Program, FKIP, Pakuan University also found sentences that have a cohesive conjunction relationship. Cohesive conjunction relationships are cohesive relationships that mark relationships that can only be fully understood through reference to other parts of the discourse. The sentence (5) mentioned earlier reflects a cohesive relationship of conjunction. Conjunction dengan in sentence (5) means a tool and is a subordinate conjunction. In addition, there is conjunction dan which is a coordinative conjunction which means addition. Following is another example of the use of interfaith conjunctions.

(6) Namun, dengan memiliki bau tak sedap namun mengharumkan nama Indonesia.

The word Namun in sentence (6) is an interalimic conjunction. However, the use of words but the second in sentence (6) is incorrect. This can use conjunction tetapi as coordinative conjunction.

Based on the data obtained in the text of the report on the research results of Indonesian Language and Literature Education Study Program students, FKIP, Pakuan University, Bogor, the following table uses the device of grammatical cohesion.

Table I

Use of Grammatical Cohesion Devices in the Text of the Report on Observation Results

\begin{tabular}{lll}
\hline No. & $\begin{array}{l}\text { Grammatical } \\
\text { Cohesion }\end{array}$ & Total \\
\hline 1 & Reference & 216 \\
\hline 2 & Substitution & 45 \\
\hline 3 & Ellipsis & 103 \\
\hline 4 & Conjunction & 350 \\
\hline
\end{tabular}

\section{Lexical Cohesion}

Lexical cohesion is a lexical relationship between parts of the discourse to get cohesive harmony of structures (Junaiyah: 39). The purpose of using the lexical aspect is to get the effect of the intensity of the meaning and the beauty of the language and the clarity of information.

Relationships or relationships using lexical elements can be done in various ways. According to Halliday and Hassan (274) dividing lexical relations into repetition, synonymy, hyponym (superordinate), antonymy, and collocation. The use of lexical cohesion in the text of the student observation report is explained as follows.

a. Repetition

In the text of the student observation report there are many uses of repetition to link clauses one with other clauses and one sentence with another sentence. Repetition is done in full, both in the form of words and phrases. The following is an example of repetition in the report text of student observation.

(7) Jenis-jenis pandan paling sedikit ada 600 jenis pandan diseluruh dunia, di antaranya adalah pandan wangi (Pandanus ammaryllifolius), pandan laut (Pandanus tectorius) dll.

(8) Pandan memberikan manfaat, seratnya dianyam untuk membuat tikar, topi, dan kerajinan lainnya. 
Repetition of the word pandan wangi and pandan laut in sentence (7) repetition of the word pandan in the phrases of jenis-jenis pandan in the previous clause. The word pandan in repetition includes hypernim from the word pandan. In addition, in sentence (8) there are repetitions of the word pandan from sentence (7). This is done to connect sentences (7) with sentences (8).

b. Synonym

The purpose of using synonyms in text is to avoid the text not boring the reader. However, in other contexts, each synonymous word may not be used interchangeably. Therefore, the accuracy of using synonyms depends on the context in the text. The cohesion device in the form of synonymy is found in the following sentence (10).

(9) Usia tanaman yang berada di Kebun Raya Bogor sangat bervariasi bisa diperkirakan tanaman yang paling tua yaitu berusia 100-200 tahun.

(10) Umur tanaman ini mencapai ratusan tahun dengan batang yang sangat keras sehingga cocok dipakai sebagai bahan bangunan, kerajinan kayu, tanaman peneduh dan tanaman pelindung, bijinya bisa dimakan dan kulit kayunya bisa dimanfaatkan sebagai obat, diameter mencapai 2,7 meter dan tinggi batang men-capai 80 meter.

The word umur in sentence (10) is a synonym of the word usia in sentence (9). The replacement of the word umur to usia is done so that the sentence is more varied.

c. Hyponym (Superordinate)

A hyponym is an expression (usually in the form of a word, but can also be a phrase or sentence) whose meaning is considered to be a part and meaning of another expression. In the text of the report on the observation of the students it was found that the use of hyponym in sentences (11), namely

(11) Kebun Raya Bogor juga memiliki tanaman langka seperti Raflesia arnoldi yang lebih dikenal dengan sebutan bunga bangkai, lalu ada Amorphopallus titanum termasuk jenis bunga raksasa, kemudian ada beberapa jenis pohonpohon berkayu yang langka misalnya pohon meranti, beringin putih, pohon eboni dan beberapa jenis mahoni.

The word Raflesia arnoldi and Amorphopallus titanum in sentence (11) are hyponymy of rare plants. In addition there are also words of pohon meranti, beringin putih, pohon eboni and beberapa jenis mahoni are hyponymy from rare woody trees.

d. Collocation
Collocation is a certain association in word choice. A selected word can always be side by side or side by side with certain other words. Collocation according to Lubis can be realized using antonyms such as the example in the antonym section.

(12) Amorphophallus ini bukan Rafflesia arnoldi adalah tumbuhan parasite yang tidak mempunyai daun, batang maupun akar.

The word Amorphophallus is associated with parasitic plants in sentence (12). It aims to associate the meaning of Amorphophallus flowers as parasitic flowers.

Based on the data of lexical cohesion in the text of the observation report of the students of the Indonesian Language and Literature Education Study Program obtained can be expressed in the form of a table as follows.

$$
\text { Table I }
$$

Use of Lexical Cohesion Devices in the Text of the Report on Observation Results

\begin{tabular}{clc}
\hline No. & Lexical Cohesion & Total \\
\hline 1 & Repetition & 339 \\
\hline 2 & Sinonimi & 2 \\
\hline 3 & Hyponymy & 15 \\
\hline 4 & Antonymy & 0 \\
\hline 5 & Collocation & 19 \\
\hline
\end{tabular}

\section{CONCLUSION}

Based on the results of the analysis and discussion, it can be concluded that there is grammatical cohesion in the text of the observation report of students of Indonesian Language and Literature Education Study Program, FKIP, Pakuan University, Bogor as evidenced by the discovery of the use of words or phrases. The tools of grammatical cohesion in the text of the observation report of students of Indonesian Language and Literature Education Study Program, FKIP, Pakuan University, Bogor include (1) grammatical cohesion in the form of reference (2), (2) grammatical cohesion in the form of recovery (substitution), (3) grammatical cohesion in the form of impingement (elipsis), and (4) grammatical cohesion in the form of conjunction. In addition, there is also the use of lexical cohesion which includes (1) lexical cohesion in the form of repetition, (2) lexical cohesion in the form of synonymy, (3) lexical cohesion in the form of hyperimi, and (4) lexical cohesion in the form of collocation.

\section{REFERENCES}

Emilia, Emi dan Frances Christie. (2012). Factual genres in English: Learning to Write, Read, and Talk about Factual Information. Bandung: Rizqi Press. 
Junaiyah H.M dan E. Zaenal Arifin. (2010). Keutuhan Wacana. Jakarta: Grasindo.

Kurniasari, Agnes Heppy. (2018). Peranti Kohesi Gramatikal dan Leksikal pada Tulisan Deskripsi Siswa Kelas VIII SMP dan Relevansinya Sebagai Materi Ajar Bahasa Indonesia. Http://Www.Jurnal.Fkip.Uns.Ac.Id/ Index.
Php/Bhs_Indonesia/Article/View/9970/7355. Diunduh tanggal 9 Mei 2018 .

Lubis, A. Hamid Hasan. (1994). Analisis Wacana Pragmatik. Bandung: Angkasa.

Moeliono, Anton M. (Ed). (1988). Tata Bahasa Baku Bahasa Indonesia. Jakarta: Balai Pustaka.

Moleang, Lexy J. (2012). Metode Penelitian Kualitatif. Bandung: Remaja Rosdakarya. 